Розділ: Психотерапевтичні модальності, методи та методики

UDK 616.895

\title{
PRELIMINARY RESULTS OF SEVERAL SMALL SAMPLE STUDIES IN THE UKRAINE, DURING TRE TRAININGS ON DIFFERENT LEVELS
}

Andreas Herold, Hildegard Nibel

Вправи для зняття напруги, стресу і травматичного досвіду (TRE) складаються з семи вправ, які стимулюють нейрогенне тремтіння. Метою цього тремтіння $\epsilon$ зменшення симптоматики посттравматичних синдромів стресових розладів ПТСР і наступних скарг, що викликаються стресом. У даній статті описуються дослідження - чи можуть сім простих фізичних вправ, які викликають тремор, поліпшити якість життя. Це можна простежити в різних субгруппах українських психіатрів і психотерапевтів, які повідомляють про великі скарги на здоров'я, в порівнянні із загальною популяцією працюючих осіб. Показники зменшення скарг, пов'язаних зі здоров'ям є статистично значущими.

Ключові слова: TRE (вправи для зняття напруги, стресу і травми) на різних рівнях, травма, стрес, ПТСР, фізичні вправи, дослідження, скарги на здоров'я, звернення за лікуванням

Tension, Stress und Trauma Releasing Exercises (TRE) are a sequence of seven exercises used to trigger neurogenic tremor. The aim of this tremor is to reduce symptoms of post-traumatic stress disorder PTSD and other stress-induced symptoms. This article describes the investigation of the effects of TRE by a standardized questionnaire which offered also space for quantitative comments. We can demonstrate that TRE do not only relief health complaints directly after the trainings, but has also a positive long term effect after some month.

Key words: Trauma, stress disorder, physical exercises, neurogenic tremor, stress release, self-regulation, trauma therapy, post-traumatic stress disorder, work strain, investigation

Упражнения для снятия напряжения, стресса и травматического опыта (TRE) состоят из семи упражнений, служащих для стимулирования нейрогенного дрожания. Целью этого дрожания является уменьшение симптоматики посттравматических синдромов стрессовых расстройств ПТСР и последующих жалоб, вызываемых стрессом. В данной статье описываются исследование - могут ли семь простых физических упражнений с целью вызывать тремор улучшить качество жизни. Это можно проследить в различных субгруппах украинских психиатров и психотерапевтов, сообщающих о больших жалобах на здоровье, в сравнении с общей популяцией работающих. Показатели уменшения жалоб, связанных со здоровьем является статистически значимым.

Ключевые слова: TRE (упражнения для снятия напряжения, стресса и травмы) на различных уровнях, травма, стресс, ПТСР, физические упражнения, исследование, жалобы на здоровье, обращение за лечением

\section{Introduction}

Today, post-traumatic stress disorder (PTSD) is more topical than ever before. The papers, 
and the news on television or the internet are always reporting on natural catastrophes such as earthquakes, floods, tsunamis, typhoons etc. In addition to this are the acts of violence caused by humans, such as domestic violence, child mistreatment and abuse, rape, acts of war, terrorism, torture, political internment etc. Accidents and medical procedures can also have a traumatic effect.

The ICD-10 definition of trauma is an "exceptional threat" or a "catastrophic level of stress, likely to cause a deep despair in almost everyone" (ICD-10: F 43.1, page 207ff.). An event that causes a trauma-related disturbance in one person may elicit a different response in another, who may recover after a certain time and show few or none of the symptoms of PTSD. The traumatic event should not just be considered from the viewpoint of the event ((severity type I - single trauma), type II - multiple trauma (Maercker 2009, page 138ff.)) but also from the perspective of personality and subjective reality (genetics, life story, social integration, resilience etc.). It is the subjective experience of the traumatic situation that is relevant, "the experience of complete helplessness, powerlessness and being at the mercy of somebody/something outside of one's control is what matters" (Wöller 2006, page $11 \mathrm{ff}$.).

Some people who go through a traumatic event go on to develop symptoms of PTSD which are extremely debilitating and prevent them from leading a normal, fulfilled life: these include intrusive thoughts, stressful dreams/nightmares, flashbacks, symptoms of dissociation and immobility, acute triggers, hyper and hypoarousal, sleep disturbances, avoidance of situations and unwanted thoughts and other symptoms such as depression, anxiety, compulsions and obsessions (Maercker 2009, page 17ff., Sachsse 2004, page 53ff.).

Each large psychotherapy school has developed its own approach to the treatment of posttraumatic stress disorder: cognitive procedure (Horowitz M.J. 2013), psychodynamic, imaginative procedure (PITT Reddemann, 2008, TRIBM Spangenberg 2015), Gestalt therapy (Butollo et al. 2002, Butollo \& Karl 2014), combined methods such as EMDR (Shapiro 1998) and brainspotting (Grand 2014), resource-oriented procedure (Sack 2010), mindfulness-based procedure (Folette et al. 2015), body-related therapies (Somatic Experiencing, Levine 1998, 2004 ), sensorimotor therapy (Ogden et al. 2010), body therapy according to Rothschild (Rothschild 2000), yoga (Emerson \& Hopper (2012)) and the procedure presented here (Tension, Stress and Trauma Releasing Exercises TRE) according to Dr. David Berceli (Berceli 2010, 2012, 2014).

From a neurobiological viewpoint, post-traumatic stress disorder PTSD may be considered as a stress processing disorder. In English, PTSD stands for post-traumatic stress disorder. The interplay between the information processing systems in the brain (sensory association fields of the neocortex, brain stem, basal ganglia, thalamus, limbic system) is reduced (Rüegg 2011). Research has shown (Van der Kolk 2000, page 200ff.) that disorders exist at the level of psychophysiological effects (over-excitation and loss of stimulus discrimination ability), neurohormonal effects (elevated level of noradrenalin, large fluctuations in cortisol concentrations (Sachsse 2004, page 48ff.), reduced serotonin concentration, increased opioid concentration and neuroanatomical effects (reduced hippocampus volume, chronic activation of the amygdala, reduced activation of Broca's center during flashbacks; Benedetti 2002).

During a traumatic event, the following are activated as a survival reaction: the psychophysical system (autonomic nervous system ANS, sympathetic and parasympathetic branch) and the neurohormonal system (activation of the hypothalamic-pituitary-adrenal axis HPA). These produce the reaction pattern of fight, flight freeze (immobility). The fight or flight response 
(heightened arousal) is triggered by the activation of the psychophysical (ANS) and neurohormonal system. Immobility, freezing (physical) and dissociation (cognitive, mental) are organized by the simultaneous activation of both branches of the ANS (Levine 2010, page 71ff., Scaer 2014, page 81ff.).

In threatening situations impulses are transmitted by the psychophysical system to the musculoskeletal system, enabling the fight, flight and freeze response. The contraction sequences follow the given reaction patterns. If, during a traumatic event, it is not possible to perform the necessary movements, habitual muscle contractions will occur, which are very frequently controlled by the procedural memory ( Scaer 2014 page $67 \mathrm{ff}$.), that lead to pain. "Myofascial pain is very commonly stress-related. Any movement of the body, that is associated in any way with previous failed defensive movements, is highly likely to activate a reflex-type tension" (Scaer 2014, page $277 \mathrm{ff}$.). Muscle cramps occur in particular in the muscle groups of the head, neck, shoulders, erector spinae muscles, hips and legs. The ilio-psoas muscles should be highlighted, as these are subject to reflex-type contractions in a threatening situation (Berceli 2012, S. 29ff.). The muscles of the foot joints, calf muscles, the quadriceps muscle, adductors, diaphragm, sternocleistomastoid muscle and masseter muscle are frequently also involved (Berceli 2014).

Modern polyvagal theory (Porges, 2011) can predict neurobiological reaction patterns more precisely by postulating two circles of defense when interacting with the environment: one is the well-known stress or fight-flight reaction. It's theory and research started with Selye in 1953(?). Much less attention was devoted to the freezing reaction, when an individual is overwhelmed by an event and experience life-threatening situations. This doesn't happen so often as the stress response, but it is quite common in man made disasters like wars or domestic physical and psychological violence, it's also modified by social engagement: if the individual is threatened alone and if she can't return within hours after the event, a post-traumatic stress is much more probable.

David Berceli, a former Catholic priest, with a $\mathrm{PhD}$ in clinical social work and a certified bioenergeticist, has lived in numerous conflict zones such as Israel/Palestine, Sudan, Uganda, Kenya, Yemen, Egypt and Lebanon. He has stayed in areas that have seen military action. Berceli reports (Berceli 2010b, Berceli DVD) that during a grenade attack during the war in Lebanon he took shelter in a cellar with eight other people of varying nationalities. While the bombs rained down, he observed everyone huddling into the fetal position. In the threatening situation the same automatic reflex-type movements were adopted by everyone. "During any traumatic experience the extensor muscles are inhibited so that the flexor muscles can contract." (Berceli 2010b, page 149). This position helps to protect the internal organs and may create a feeling of safety. As already stated above, the following muscles are primarily involved: the calf muscles, the quadriceps muscle, the adductors, the diaphragm, the neck muscles and the muscles of mastication. The main muscle groups that contract in a threatening situation are the ilio-psoas muscle, the trunk, including the pelvis and legs. The ilio-psoas contracts when we assume the fetal position. The compensatory reaction of the erector spinae muscles leads to chronic backache in numerous traumatized people, since the tension in the ilio-psoas is chronically increased.

Berceli has observed that many people who have been traumatized go on to develop a spontaneous tremor. Many attempt to suppress this reaction. Children tremble spontaneously. The tremor in adults is often prevented in the presence of children, so that children do not interpret this tremor as anxiety of the adults (Berceli 2010, page 47ff.). "Tremor is essentially a natural 
mechanism of the body, so that it can discharge the high level of tension and chemical substances which overload the body at the time of a traumatic incident. The trembling process discharges the body of excessive energy and it returns to a state of rest and relaxation. In fact the ability to shake off a trauma is one of the most archaic reactions of the human animal (Berceli 2012, page 33).

Peter Levine, founder of Somatic Experiencing Trauma Healing, also describes how, after an accident when he was run over by a car, he was "overcome by a spontaneous tremor that was able to discharge enormous survival energy" (Levine 2010, page 34) (...) "that he had learned to accept and welcome primitive tremors and trembling and spontaneous body movements, instead of fearing and suppressing them" (Levine 2010, page 38).

Behavioral biology has taught us that following life-threatening situations (attack by a predator), mammals shake off the pent-up energy during the flight reaction or freeze reaction. There are numerous videos on YouTube that document this tremor. It is a natural mechanism that helps mammals to discharge the compressed energy following a threat and allows them to continue to live "normal" lives. Mammals in the wild are not able to develop PTSD, because after developing the freeze reaction after being attacked by prey, they always develop this tremor response. In Levine's (Levine 1997, 2010) Somatic Experiencing Trauma Healing (SE), the concept of discharge of pentup energy represents a primary feature in the treatment of PTSD. "Trauma symptoms are not caused by the external event. They develop when excessive energy is not discharged by the body. This energy remains trapped in the nervous system and can have a devastating impact on body and mind" (Levine O.J,B1.4 ).

The TRE exercises may be used in groups, in individual therapy and as a self-help method alone at home.

The subjective effect of the tremor triggered by the seven TRE exercises (see below for description of the exercises) is experienced by almost all people as a feeling of peace and relaxation, a reduction of hyperarousal, an improved body image, a greater ability to tolerate affects (containment) and an enlarged "Window of Tolerance" (Ogden et al. 2010, page 67ff).

According to Scaer (2007, page 19ff.) (Berceli 2010a, page 3ff.), the tremor mechanism can reduce or inhibit the activity of the amygdala, so that the neuronal networks with trauma content become slowly erased in the procedural memory. The neurogenic tremor appears to be able to perturbate negative affects by connecting them with positive memories of safety and positive social encounters.

\section{Method}

As the TRE exercises are quite a recent development in trauma therapy, there are only very few studies on it's effects (Berceli ?, Nibel 2014). Till now very few intervention studies are conducted to investigate the effects of the TRE exercises on the theoretically proposed stress reactions of fight/flight and freezing. For this purpose we used a questionnaire developed by the German labor agency to track the changes in work life of employees. During the period of industrialization in Western countries scientists concentrated their attention on physical issues causing health disorders on the workforce. As there is a shift from physical to mental strain, these more subtle changes are measured by a questionnaire, asking for all kinds of work load like time pressure, exposition to physical and chemical factors, but also organizational deficits or poor cooperation with supervisors and colleagues. As dependent variable 25 different types of health 
complaints are offered to mark. Furthermore eight different aspects of job satisfaction are measured, as it is well known that they mediate the stress reaction. Besides, the economic condition of the organization and the individual risk of unemployment were measured.

Meanwhile the changing work life is of growing importance in all European countries. There is an organization founded, EuroFound, which tracks the quality of employment and working conditions every five years in 27 European countries.

Out research is two fold: on one hand we want to show, that not only physical strain can cause tremendous negative effects on physical health and well-being, but also dealing with psychological stress like psychotherapists do, suffering from secondary traumatization, can decrease physical well-being massively. Till now, there is a strong belief among labor scientists, that physical health complaints are a problem among blue collar workers or particularly demanding jobs like nurses or policemen. With our data we can show, that health problems are also a big issue among high prestigious academics like doctors and psychologists.

Furthermore we investigated the effects of these TRE exercises on the well-being of the psychotherapists. Our hypothesis is, that TRE can improve health complaints, especially those hypothesized by the polyvagal theory like chronic pain, vigor, proneness to infections and difficulties to breath, sleeping disturbances, normalizing heart beat (either tachicardia or irregular heart beat in bradycardia, which is typical for the freezing reaction), chronic fatigue, emotional numbness and depression. The sequence of the trainings is compulsory: participants have to attend the TRE I-training before they can continue to the TRE II-training. This made it possible for us to do a intervention study, measuring the work conditions and the health status in the beginning of May 2016, and again at the end of August in 2016.

Sample subjects were psychotherapist, either with a Master in medicine or psychology who participated in the different TRE group trainings in different Ucrainian cities between March 2016 to August 2016. The groups consisted of about 12 to 30 participants., the trainer is an experienced psychotherapist, who speaks and understands the local language.

Sample

The table shows the number of participants in the various training groups, as well as some demographic indicators:

\begin{tabular}{|l|l|l|l|}
\hline TRE training Level & TRE I & TRE II & $\begin{array}{l}\text { TRE } \\
\text { advanced training }\end{array}$ \\
\hline $\begin{array}{l}\text { April: } \text { Kiev } \\
\text { (metropolitan, South) }\end{array}$ & & $\begin{array}{l}\mathrm{n}=24 \\
(10 \mathrm{f}, 5 \mathrm{~m}) \\
\text { age } 43.2 \text { (mean); } \\
8 \mathrm{MA}, 2 \mathrm{PhDs}, \\
1 \text { in a vocational } \\
\text { training }\end{array}$ & \\
\hline $\begin{array}{l}\text { March: } \\
\text { Chaikov } \\
\text { (rural, East) }\end{array}$ & $\mathrm{n}=20$ & \\
& $\begin{array}{l}\text { age } 37.3 \text { years (mean) } \\
12 \mathrm{f}, 8 \mathrm{~m} \\
8 \mathrm{MA}, 3 \mathrm{PhD}, 2 \\
\text { vocational training }\end{array}$ & \\
\hline
\end{tabular}




\begin{tabular}{|c|c|c|c|}
\hline $\begin{array}{l}\text { TRE training Level } \\
\text { Date \& Town }\end{array}$ & TRE I & TRE II & $\begin{array}{l}\text { TRE } \\
\text { advanced training }\end{array}$ \\
\hline $\begin{array}{l}\text { May + August: } \\
\text { Charkov } \\
\text { (rural, East) }\end{array}$ & $\begin{array}{l}\mathrm{n}=30 \\
(10 \mathrm{f}, 5 \mathrm{~m}) \\
\text { age } 43.9 \text { years (mean); } \\
\text { MA } 23,3 \mathrm{PhD}, \\
4 \text { in a vocational } \\
\text { training }\end{array}$ & $\begin{array}{l}\mathrm{n}=20 \\
(19 \mathrm{f}, 1 \mathrm{~m}) \\
\text { age } 48.6 \text { years (mean) } \\
5 \mathrm{MA}, 3 \mathrm{PhD}, \\
1 \text { other, } \\
1 \text { missing value }\end{array}$ & \\
\hline $\begin{array}{l}\text { June: } \\
\text { Chmelinizky } \\
\text { (rural, East) }\end{array}$ & & & $\begin{array}{l}\mathrm{n}=16 \\
(10 \mathrm{f}, 5 \mathrm{~m}) \\
\text { age } 39.7 \text { years } \\
\text { (mean); } \\
\text { MA } 14,2 \text { other }\end{array}$ \\
\hline
\end{tabular}

\section{Results}

First, we present the data of the 71 subjects in the four TRE training groups who completed the questionnaires at the beginning and end of the trainings. Our table shows the means of the different groups and the most important indicators like job satisfaction, strain and stress reaction (health complaints), over-all pain und health condition for the

\begin{tabular}{|c|c|c|c|c|c|}
\hline $\begin{array}{l}\text { TRE } \\
\text { training }\end{array}$ & $\begin{array}{l}\text { job satisfaction } \\
\text { (4 point scale, } 4 \\
\text { max., } \\
0 \text { min.) }\end{array}$ & $\begin{array}{l}\text { job strain } \\
\text { ( } 3 \text { point scale, } 0 \\
\text { no strain, } \\
2 \text { strong) }\end{array}$ & $\begin{array}{l}\text { health } \\
\text { complaints } \\
(\max 25 \text {, } \\
\min 0)\end{array}$ & $\begin{array}{l}\text { pain } \\
(6 \text { point scale } \\
\min 0, \\
\max .5)\end{array}$ & $\begin{array}{l}\text { health status } \\
(6 \text { point scale, } \\
\min 0, \\
\max .5)\end{array}$ \\
\hline March & 3.2 & .41 & 6.85 & 1.35 & 3.5 \\
\hline April & 2.96 & .40 & 8.18 & 2.09 & 2.82 \\
\hline Mai & 3.23 & .46 & 9.08 & 1.82 & 2.95 \\
\hline June & 2.86 & .74 & 8.19 & 1.91 & 2.73 \\
\hline August & 2.95 & .57 & 6.65 & 1.6 & 3.00 \\
\hline
\end{tabular}

Tab 1: Mean of different indicators of work and health conditions before the different TRE trainings $(n=71)$.

All the values of quality of work life are comparable to those in the Western countries, concerning job satisfaction, job strain or health status. Except the health complaints are much higher than in Western European countries. The average health complaints there vary between 4 to 7 symptoms, while within these Ukrainian data the average number of health complaints varies between 6 and 9 symptoms. These higher level of complaints can be explained by at least two hypotheses: 
either a general higher stress level, caused by the political and economic changes within the last 20 years, socio-economical insecurities, the threat of the conflict in the Eastern Ukraine or the secondary traumatization by treating strongly traumatized patients.

Furthermore the data follow our hypotheses: job strain correlates negatively with job satisfaction and health status, but positively with health complaints and pain; meanwhile job satisfaction correlates negatively with health complaints $(-.08-.29)$ and pain, but positively with health status $(.15-.53)$ in the different samples.

\begin{tabular}{|l|c|c|c|}
\hline TRE training & $\begin{array}{l}\text { health complaints } \\
(\max 25, \min 0)\end{array}$ & $\begin{array}{l}\text { pain } \\
\text { (6 point scale min } \\
\text { 0, max. 5) }\end{array}$ & $\begin{array}{l}\text { health status } \\
\text { (6 point scale min } \\
\text { 0, max. 5) }\end{array}$ \\
\hline March & 2.06 & 1.35 & 3.32 \\
\hline April & 1.91 & 1.91 & 3.0 \\
\hline Mai & 2.52 & 1.48 & 3.45 \\
\hline June & 1.94 & 1.93 & 3.07 \\
\hline August & 3.58 & 1.29 & 2.82 \\
\hline
\end{tabular}

Tab 2: Mean of different indicators of work and health conditions after the TRE trainings $(n=71)$.

As it is typical for traumatized persons we found these specific symptoms for PTSD increased, compared to representative samples of the European work condition survey: heart, stomach/digestion problems, dizziness, nervousness and sleeping disorders.

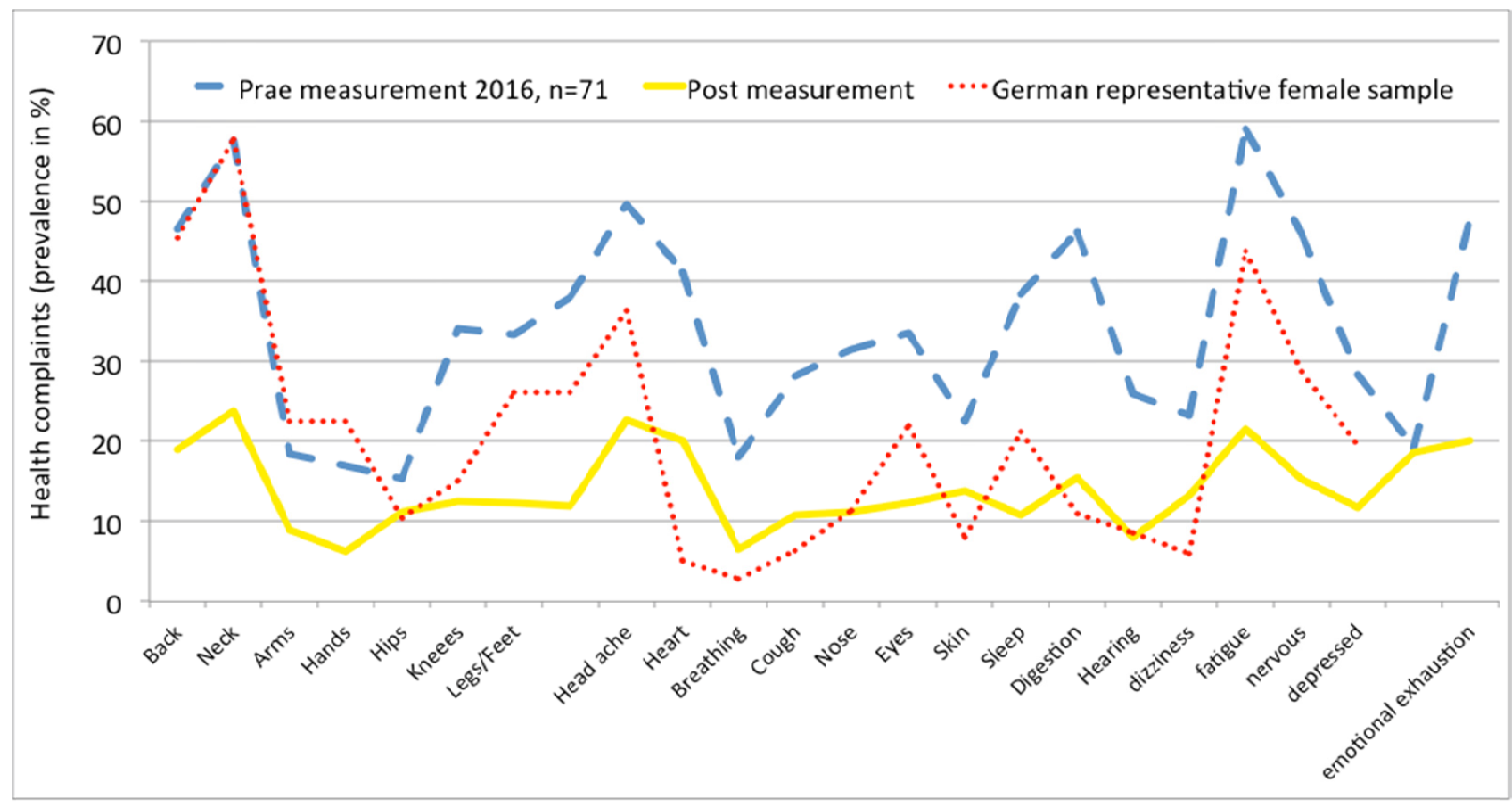

Chart 1: 12-months prevalence before and incidence of health complaints after the different TRE trainings over all subjects. 


\section{Intervention study}

12 Subjects participated in the TRE I provider training the beginning of May and in the TRE II training in the mid of August. So we can compare the effects of TRE training on different health indicators. We also can demonstrate that the working conditions and economic situation were stable, so the changes are not attributable to improvements in the general living conditions (NZZ Neue Zürcher Zeitung 16. September 2016, Kiews harter Weg über den Berg, p. 29). The data show the expected decrease of all indicators in the expected direction of reliefing health complaints. From a clinical point of view these decreases are impressing, particularly regarding the improvements of specific symptoms like pain in the knees, dizziness, depressive mood and emotional exhaustion. From a general overview the decrease of 3 symptoms from 10,3 to 7.1 is definitely improving the well-being of the subjects.

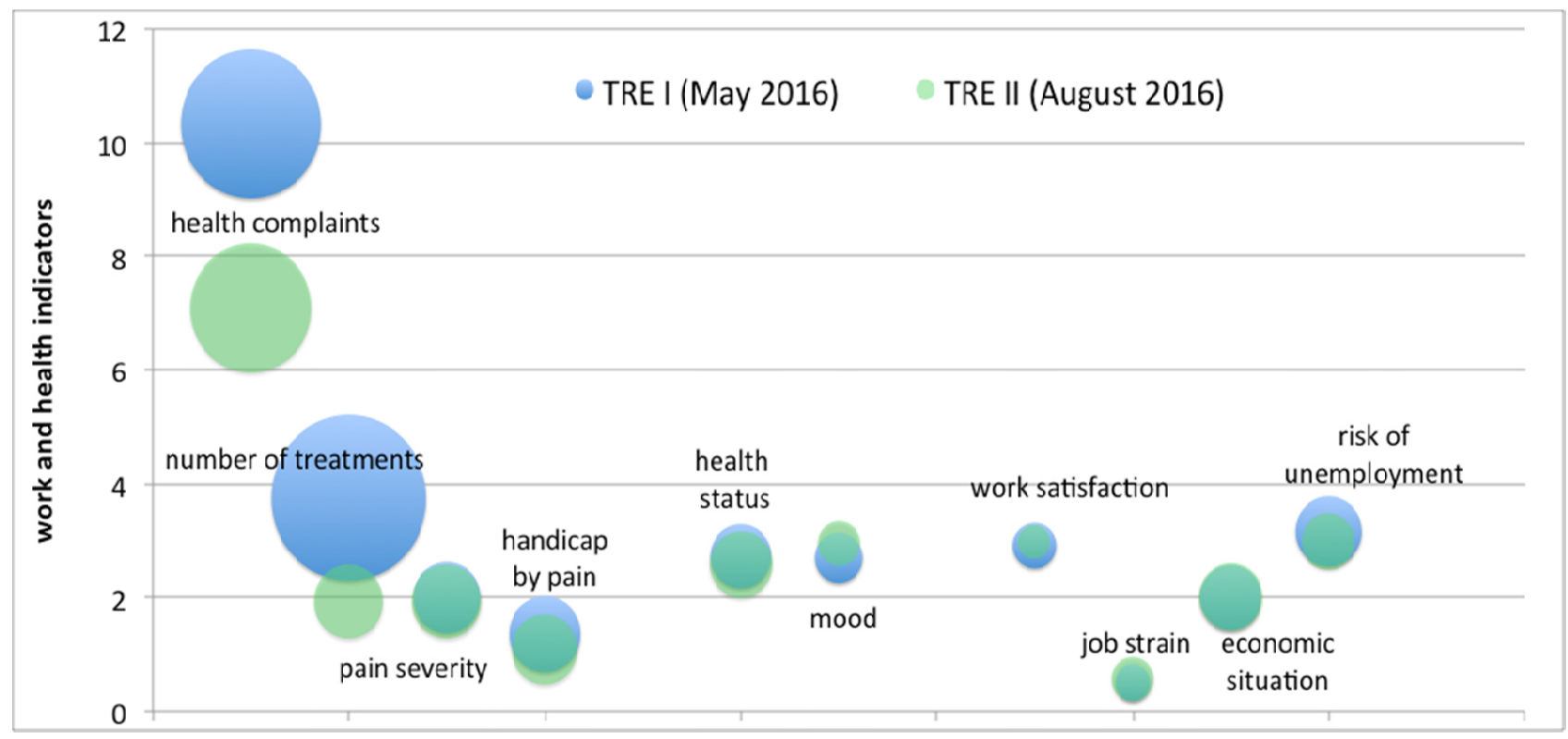

Chart 2: Pre-post measurement of several health indicators in the intervention sample $(n=12)$.

Furthermore, claiming treatment for the symptoms decreases by almost half. This might be an interesting message for our health care system: it is possible to improve health condition of a vulnerable group of the work force by very simple measures.

Parallel to the quantitative increases of mood subjects reported spontaneously qualitative improvements of their quality of life, like feeling energized, better feeling in the body and relief of psychological and physical tension in general. In terms of stress or polyvagal theory this is releasing the freezing reaction with it's high muscle tension, dissociation, numbness, flattening of affects etc.

\section{Discussion and Conclusions}

Our aim was to investigate whether seven simple physical exercises can release physical symptoms and improve the quality of life. This could be shown in different subsamples of psychiatrists and psychotherapists, who suffered from a lot of health complaints, compared to representative samples of the working population. Furthermore there seem to be a typical pattern of 
symptoms like heart and digestion problems, sleeping disorders and fatigue, which can be explained by the polyvagal theory. These findings are particularly intrigueing as these samples are not exposed to poor physical work conditions. Their work load consists mostly of dealing with negative emotions of their clients.

Although only the decrease of health complaints became statistically significant we interpret these data that it is worth doing more research on the TRE as promising healing technique to help heavily traumatized subjects to whom the benefit of psychotherapeutic techniques seem to be limited. Additionally, it could be shown that claiming treatments of the health systems decreased at least about $50 \%$. We think that these data are at least clinically relevant.

Of course, the TRE technique ought to be studied in other samples and compared to usual medical treatments to find out, were the limits and possibilities are to improve quality of life of our patients and of ourselves as professional helpers.

\section{References}

Ahn, H. \& Wampold, B.E. (2001), Wher oh where are the specific Ingredients? A MetaAnalysis of Component Studies in Counseling and Psychotherapy. Journal of Counseling Psychology 48 (3), 251-257.

Benedetti, F. ((2002), How the Doctor`s Words Affect the Patients Brain. Evaluation \& the Health Professionals, 25 (4), 369-386.

Berceli, D. (2010), The Revolutionary Trauma Release Process, Vancouver: Namaste.

Berceli, D. (2010a), The Effects of Neurogenic Tremors on the Human Body, Manuscript.

Berceli, D. (2010b), Neurogenes Zittern. Eine Körperorientierte Behandlungsmethode für Traumata in grossen Bevölkerungsgruppen, in: Trauma \& Gewalt, 4. Jahrgang, Heft 2/2010, S. $149 \mathrm{ff}$.

Berceli, D. (2012), Körperübungen für die Traumaheilung, Papenburg: Niba-ev.

Berceli, D. (2014), Powerpoint Modul I.

Berceli, D. (Hrsg.) (2015) Shake it off Naturally, o.O.: Create Space Independent Publishing Platform.

Berceli, D. (o.J.) DVD The Revolutionary Trauma Release Exercises, Namaste Publishing.

Bohne, M. (2014), Reden reicht nicht. Eröffnungsvortrag auf der Tagung "Reden reicht nicht", Heidelberg, 2.-5. Mai 2014.

Bohus, M. (2014), Wie profitiert die therapeutische Praxis von der neubiologischen Forschung. Das Rätsel der Dissoziation. Vortrag auf der Tagung "Reden reicht nicht", Heidelberg, 2.-5. Mai 2014.

Butollo, W., Hagl M, Krüsmann M (1998), Leben nach dem Trauma, München: Pfeiffer.

Butollo, W., Karl R (2012), Dialogische Traumatherapie, Stuttgart: Klett-Cotta.

Emerson, D, Hopper, E (2012), Trauma-Yoga, Heilung durch sorgsame Körperarbeit, Lichtenau/Westfalen: Probst.

Eschenröder, C. (2014, Wie wirksam sind Techniken der Energetischen Psychotherapie, die Exposition mit sensorischer Stimulierung verbindet? Psychotherapeutenjournal 2, 149-155.

Follete, V.M., et al. (2015), Mindfullness-Oriented Interventions for Trauma, New York, London: Guilford.

Geller, S. \& Porges, S. (2014). Therapeutic Presence: Neurophysiological Mechanisms 
Mediating Feeling Safe in Therapeutic Relationships. Journal of Psychotherapy Integration, Vol. 24, No. 3, 178-192

Grand, D. (2014), Brainspotting, Kirchzarten: VAK.

Grunwald, M. (2014). Neurobiologische Funktionen von Selbst- und Fremdberührungen. Vortrag auf dem internationalen Kongress "Reden reicht nicht", Heidelberg, 2.-5. Mai 2014.

Horowitz MJ (2013), Stress Response Syndromes, PTSD, Grief, Adjustment and Dissociative Disorders, Lanham Maryland: Jason Aronson.

Krummenacher, P. \& Gaab, J. (2013) Klinische Nutzung der Placeboreaktion. PSYCHup2date 7, 199-201.

Levine, P. (1998), Trauma-Heilung, Essen: Synthesis.

Levine, P. (2010), Sprache ohne Worte, München: Kösel.

Levine, P. (o.J.), Manuel Somatic Experiencing Training, Das erste Jahr, B1.4.

Neue Zürcher Zeitung 16. September 2016, Kiews harter Weg über den Berg, p. 29

Ogden, P. Minton K, Pain C (2010), Trauma und Körper, Paderborn: Junfermann.

Porges, S. (2011). The polyvagal theory. Norton \& Company, 2011

Reddemann, L (2004), Psychodynamisch Imaginative Traumatherapie PITT - Das Manual, Stuttgart: Klett-Cotta.

Rothschild, B. (2000), The Body Remembers, New York: Northon.

Rüegg, J,K. ( 2011), Gehirn, Psyche und Körper, Stuttgart: Schattauer.

Sack, M. (2010), Schonende Traumatherapie, Stuttgart: Schattauer.

Scaer, R. (2007), The Body Bears the Burden, New York, London: Routledge.

Scaer, R. (2014), Das Trauma-Spektrum, Lichtenau/Westfalen: Probst.

Seidler, K. (2006), Geburt, Tod und Wiedergeburt des Dodo-Vogels: Mythen der Psychotherapie und Psychotherapieforschung. Psychotherapieforum14, 146-152.

Shapiro, F. (1998), EMDR, Grundlagen und Praxis, Paderborn: Junfermann.

Spangenberg, E. (2015), Behutsame Trauma-Integration (TRIMB), Stuttgart: Klett-Cotta.

Spitale, I. et al. (2008), Wirksamkeitsvergleich zwischen Hypnotherapie und Körperpsychotherapie. Eine Studie zur Praxisevaluation. Download MEI Tübingen, abgerufen am 28.7.2016 http://www.meg-tuebingen.de/downloads/200804\%20Hypnotherapie\%20und\%20Koerperherapie\%20Zus.pdf

Tschuschke, V. (2014), Zur aktuellen Lage der Psychotherapieforschung und ihrer Auswirkungen - Irrwege und Auswege. Vortrag auf dem internationalen Kongress "Reden reicht nicht", Heidelberg, 2.-5. Mai 2014. 